\title{
Teachers' Adversity Quotient Dimension of Ownership: Predictor of Students' Academic Performance in Public Secondary Schools in Kenya
}

\author{
Marycasta Mwivanda $^{1} \quad$ Petronilla Kingi ${ }^{2}$ \\ 1. School of education, Kenyatta University, P.O. Box 43844-00100, Nairobi, Kenya \\ 2. School of Education, University of Nairobi, P.O Box 30197, GPO, Nairobi. Kenya
}

\begin{abstract}
Given the high degree of performance expected from teachers', their ability to respond to adversity is crucial. This study sought to determine the relationship between teachers' Adversity Quotient dimension of ownership and students' academic performance. The study involved 441 teachers chosen though systemic random sampling. Data was collected by use of adversity quotient profile questionnaires and Kenya certificate of secondary school results for students' academic performance. Data was analyzed using Pearson correlation coefficient (r) and regression statistics to ascertain relationships. The results showed strong significant relationship $(\mathrm{r}=.392, \mathrm{P}<0.01$ and $\mathrm{t}=9.939, \mathrm{P}=0.01$. The study concluded that teachers' ownership dimension of adversity quotient is important towards improving students' academic performance.
\end{abstract}

Keywords: adversity, adversity quotient, ownership dimension, students' academic performance.

DOI: $10.7176 / \mathrm{JEP} / 11-27-03$

Publication date:September $30^{\text {th }} 2020$

\section{Introduction}

Given the fact that people experience different adversities in work places, they are expected to demonstrate high degree of adversity quotient. Resilience, according to Venkatesh and Shivaranjani (2016); Bautista, 2015; Yazon \& Manaig, 2018; Khairazani \& Abdulla, 2018) is not an inborn trait. Adversity quotient has been applied in political field, entrepreneurship, hospital staff and insurance agents, education and provided positive results as a predictor of success (Bautista, 2015). In education, recurrent internal and external challenges include complex duties and responsibilities which are critical in achieving organizational goals. Adversity complexities include conflicts among education stakeholders, academic requirements, heavy workloads, and even emotional stressors coming from personal and peer pressure. Such adversities may also be in the form of sudden loss of a loved one, natural calamities, terrorist attacks, and other events that impact on emotional state of an individual teacher. Personal and environmental adversities may affect people of different sex, and professional qualification including those in educational setting. Ferrer (2009) indicates the need to face adversities and a sustained interest in achieving organizational outcomes. Adversity quotient includes accountability which gauges the degree to which one is able to rise above unnecessary blame, whether on oneself or others (Thi, 2015; Kusumawati, 2017); Hidayat \& Sariningsih, 2018). It recognizes one's share of responsibility in a challenging situation and leads to action of providing solution.

The benefits of adversity quotient become apparent by examining a broad array of functioning practices on how teachers maintain a state of well-being while dealing with stressors in work environments. Studies have shown that adversity quotient is a predictor of students' academic performance, Albdelkarim, and Abuiyada (2016); Tigchelaar and Khaled (2015) Bautista (2015). This was confirmed by Matore et. al. (2015); Parvathy et. al. (2014) that in education perspective, AQ is the ability needed by struggling teachers to achieve educational goals. Parvathy et. al. (2014) further argued that teachers with good AQ will be able to endure in facing various difficulties in the teaching and learning process. They therefore argue that it is necessary for teachers to acquire AQ for the purpose of better performance of duties. However, Isidro \& Ablana (2015); Alberto \& Manaig (2019 found a negative correlation between adversity quotient and job performance. According to Dorji (2019) AQ provides an avenue for learners to improve their creative and logical reasoning in different subjects. It can be used to improve students' academic performance. It prepares students to resist hardships and build their confidence level as well as increase their learning motivation, encouraging them to be enthusiastic about learning.

There are numerous dimensions of AQ which underlie the measurement of this tool with regard to work performance. According to Stoltz (2006) there are four dimension of AQ, namely, control, origin and ownership, reach and endurance. The dimension of control relates to the ability to control, respond and improve difficult situations. People with high AQ are likely to display superior response to challenges and are able to manage adverse situations better than those low in AQ. They take upon themselves to do something regardless of the cause. Such people hold themselves responsible for dealing with adverse situations without blaming themselves, others or bad situations. Those with low AQ blame people of bad situations for adverse situations. Reach refers to the extent to which difficulty is derived to permeate life. Those who let adversity spread to all areas of their lives give 
up and lose hope to do something about the challenges they face. Endurance reflects how a person perceives the difficulty and therefore their capability to endure in passing through it. It relates to the duration a person perceives adversity to last. People with high AQ are optimistic while dealing with adversity while those with low AQ are doomed to fail as they perceive adversity as permanent (Daloos,2015). These dimensions of AQ are applicable in school situation, and can be measured to produces an overall score that determines the teachers' capacity to face difficulty.

There are different aspects of adversity quotient in practice that can affect performance in schools. For example, Stolz (2000), categorized adversity quotient into three groups, namely, quitter type (low AQ), camper type (medium AQ), and climber type (high AQ). Quitter type is typical of teachers who get away from the problems they face in school. This is characterized by minimal effort, when confronted with difficulty and one tends to retreat and avoid problem. Teachers with quitter type are those who think that students are slow learners and cannot understand new concepts. They lack self-motivation, so when they encounter difficulties in the course of their duties will give up and stop with effortless. Camper type is typical of teachers who avoid taking risks and are satisfied with their status quo. Such teachers have the capacity to stretch to the maximum but they don't. They do not see the need for pushing students to their full potential. Climber type is typical of teachers who set goals and targets. To achieve those goals, they try to achieve them with perseverance. Besides, they also have courage and high discipline. Teachers who are climbers are those who produce better output in terms of students' academic performance by adding value to their students' grades.

We live in a world of constant change particularly with new innovations and technology which may have impact on whatever topic we are researching. One way of improving students' academic performance is by enhancing teachers' adversity quotient. In Kenya Teachers are facing many adversities in their teaching career which they must contend with. Such adversities include high enrollment, use of technology, disease, students' indiscipline, wars pandemics,conflicts with employers among many others. All these adversities have a negative impact on students' academic performance and have resulted in decreased students' academic performance in the last decade. Although there is a wealth of research on this topic, no research has been done on teachers' adversity quotient, most researches were done outside the country and the context is significantly different. Second, previous studies have limitations in terms of methodology. Consequently, these studies have produced general findings and this situation may not be adequate in guiding the practitioners to clearly understand the complexity of adversity quotient construct in diverse cultural backgrounds. This study therefore sought to establish the relationship between teacher's adversity quotient dimension of ownership on basis of teachers' professional qualification, length of service and students' academic performance in Nairobi and Kiambu Counties in Kenya. This was done by use of adversity response profile questionnaire developed by Stoltz (2010) to measure teachers' ownership dimension of adversity quotient on a five point Likert scale and the Kenya certificate of secondary education results for the years 2015 and 2016 was used as a standardized measure for students' academic performance. The study was guided by the following hypothesis:

i) Ho1: Is there a significant difference between the teachers' adversity quotient dimension of ownership when they are classified according to a) professional qualification? b) length of service?

ii) ii) $\mathbf{H}_{02}$ : There is no significant relationship between teachers Adversity Quotient dimension of ownership and students' academic performance.

\subsection{Literature Review}

One of the characteristic that determine success or failure in performance outcomes in work place is the ownership of adversity. People with high adversity quotient have a characteristic that makes them to adapt to drastic changes in life. High adversity quotient people tend to be responsible and inspire others towards commitment. The ownership dimension of adversity explains the extent to which a person is able to rise above difficulties, whether it is excessive blame on oneself or on others. For example, Stoltz (2010) and Shen (2014); Venkatesh et al., (2015) state that blame is a none-productive activity which destroys a person's energy, hope and self-worth. According to Lo \& Khaled (2015), lack of ownership of adversity results to blaming others which is none-productive game in the workplace. Further study by Yazon \& Manaig (2019) examined the relationship between adversity quotient, emotional quotient and students' academic performance. Purposive sampling was employed since there are only 30 student-parents enrolled in the university. Chi Square Test was utilized to test the relationship between the variable. The results revealed that there was significant relationship between students' academic performance and ownership their ownership of adversity. Responsible parents made continuous follow up and consultation with their child's teachers and their children performed better academically than those who abandon their children at school. However, the study revealed no significant relationship between student-parents' emotional quotient, adversity quotient, and academic performance.

Adversity inspires people to reflect deeply about their ugly, venomous situation and wears, yet a precious tool in creating a positive environment. In this process of demonstrating good comprehension of adversities they create healthy interdependence, greater agility and authentic trust among all stakeholders especially in education 
(Shen, 2014; Venkatesh et al., 2015). Adversity quotient creates a positive environment at work which in turn leads to ownership of adversity, teamwork, innovation and responsibility among teachers. According to Korna (2014) teachers who are responsible are capable of helping students to solve small and big challenges in their academic journey. Studies by Bautista, 2015; Hechanova, Waelde, Dolena et al., 2015) all indicate high ownership score at the face of adversity translates to high work performance. Bautista (2015) examined the relationship between adversity quotient and teaching performance of 30 faculty members at Lambunao University. The study focused on respondent's profile, adversity quotient, and the performance outcomes. The faculty members had high adversity quotient and good teaching performance. Faculty members who were classified according to their age and academic rank had high adversity quotient. However, when they were classified according to length of service, those who served the school for more than 20 years had high adversity quotient while those who served less than 20 years had average adversity quotient. Results of the t-test showed that there is a significant difference in the adversity quotient of faculty members when they were classified according to their academic rank and length of service. Results of Pearson's $r$ showed that there is a significant relationship between adversity quotient and teaching performance of faculty members.

Further research indicates that people with high adversity quotient are more likely to accept their challenges and to succeed in life. For example, a study by Kekhet (2015) found that adversity quotient of leaders influenced their transformational leadership style. Similarly, Khairani and Abdullah (2018) examined a correlation study to determine the relationship between adversity quotient and academic well-being among Malaysian undergraduates facing challenges of identity exploration. A questionnaire was administered to undergraduates in the School of Pharmacy and the School of Medical Sciences $(n=348,70$ males and 278 females). Independent sample t-test, one-way ANOVA and Pearson correlation were employed. The findings show that there are no significant differences in the mean score of adversity quotient between male and female undergraduates. There were also no significant differences in the mean score of academic well-being between male and female undergraduates. However, $1^{\text {st }}$ year undergraduates report significantly lower mean adversity quotient scores when compared to 2 nd and 3rd year undergraduates. The mean score for academic well-being for 1st year undergraduates was significantly lower compared to 2 nd and 3rd year undergraduates. Primary analysis shows that adversity quotient and academic well-being are positively correlated. Adversity quotient is a key construct in improving the adaptability of undergraduates to face challenges. The construct has a positive and strong relationship with academic well-being. It is evident from these studies that adversity quotient and the dimension of ownership are important in enhancing performance and hence the need to establish the effect of teachers' ownership dimension of adversity quotient on students' academic performance.

The Ownership dimension of the AQ theory seems to be the core of a person's success at work (Bautista, 2015). However, there seems to be no present empirical data that demonstrates its significance in relation to the teaching profession. This study therefore sought to establish the effects of the ownership dimension of adversity quotient on students' academic performance. Good understanding of ownership of adversities creates health interdependence, greater alertness and genuine trust among education stakeholders leading to improvement in performance outcome (Khairani \& Abdullah 2018). This positive environment in schools and among the teachers in turn leads to teamwork, innovation and quality academic performance among the students' (Musili, 2015).

The research literature has been used as foundation of establishing a conceptual scheme for this study as exhibited in Figure 1.

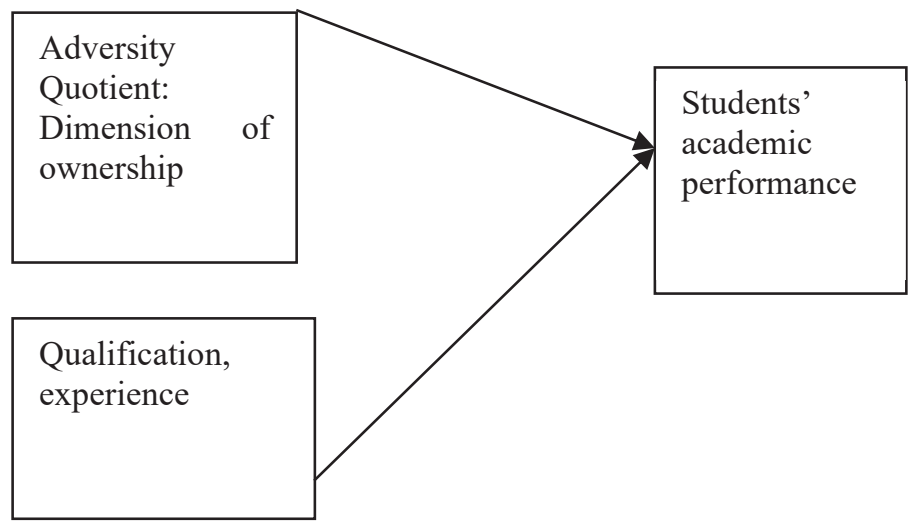

\section{Fig.1: Conceptual frame work}

The Fig 1 above shows the relationship between variables in the study. It is conceptualized that teachers adversity quotient dimension of ownership, enhances students' academic performance. Teachers with high score in ownership dimension are able to handle adversities in school and in class effectively and this will transform to 
high scores of their students' academic performance in KCSE. Teacher's adversity quotient can be influenced by extraneous variables such as teacher's professional qualification and length of service. Teachers' demographic variables of professional qualification and experience are expected to impact students' academic performance positively. A study by Musili (2015) and Bautista (2015) showed that teachers with higher academic qualifications posted tended to post better students' academic grades than those with lower professional qualification, however a study by Musau and Aberi (2015) found no significant difference between teacher qualification and students' performance in SMT subjects at form four level $\mathrm{F}(1,37)=0.017, \mathrm{P}>0.05$. In a study by Oluwakeni and Otukayonde (2015) found that teachers teaching experience has significant influence in students' academic performance. Teachers with teaching experience of 10 years and above recorded better students' academic grades than those with less than experience.

This study was underpinned on the adversity quotient theory by Stoltz (1997). Adversity quotient is related to attribution theory (Bautista, 2015). Adversity quotient is the science of a persons' resilience during adversity. It is a score that measure a persons' ability to deal with adversities and the pressures in life and at work. Adversity quotient is made up of four dimensions: control, ownership, reach and endurance. Ownership dimension of adversity quotient is the ability to accept responsibility and be accountable of the adversities experienced in work place. High score in all the four dimensions of adversity quotient accounts for success in life or work. People with high ownership level of adversity will take action in dealing with the adversities (Bautista, 2015). It is assumed that ownership dimension of adversity quotient is responsible for action of change during adversity. This study sought to establish the relationship between teachers' adversity quotient ownership dimension and students' academic performance in public secondary schools in Kenya. This theory is related to this study as it explored if there was any significant relationship between teachers' adversity quotient dimension of ownership and their students' academic performance.

\section{Methodology and Study paradigm}

This study adopted a mixed design approach. This is a research design that utilizes both qualitative and quantitative forms (Creswell 2009). It sought to determine the relationship between teachers' adversity quotient dimension of ownership and students' academic performance in Kenya certificate of secondary school results in Kiambu and Nairobi Counties, Kenya for the years 2015 and 2016. Specifically, it answered the following questions: 1) What is the teachers' adversity quotient dimension of ownership when classified according to a) professional qualification and b) length of service? 2) Is there a significant relationship between teachers' adversity quotient of ownership and students' academic performance?

This study was conducted among four hundred (441) teachers in Kiambu and Nairobi County. There were three instruments used to gather data for the study. They were: a) Secondary school teachers profile which provided information about the respondents' personal background information such as professional qualification and length of service, b) Adversity quotient profile - this instrument was developed by Paul Stoltz (1997) and was adopted for this study, c) Students KCSE results 2015-2016 - this instrument measured the students' academic performance and was provided through KCSE results for 2015 and 2016 recorded by each teacher. This was a structured questionnaire that was to be filled by the teachers. It had three sections. Part A: demographic information of the teachers, part B, the teachers' subject KCSE results for the years 2015 and 2016, and part C, the questions of adversity quotient profile for the teacher. The adversity profile was arranged into four sections control, ownership, reach and endurance. The adversity quotient profile questionnaire had 10 questions on ownership measured on five point Likert scale whereby 5 represented high ownership score, 4 above average, 3 average: 2 below average and 1 low. The respondents were to show to what extent they felt responsible for an adverse situation in school. Either they were responsible to great extent or not responsible at all. The computed scores for ownership were grades as follows: 50 (high); 47-49 (above average); 41-46 (Average); 31-40 (below average); and 10-30 (Low).The instrument used was an adversity quotient questionnaire which was developed using a Likert scale model consisting of 20 items. Each of the four dimensions of AQ reliability was ascertained using Cronbach alpha and the reliability for dimension of ownership was 0.734 . The average KCSE mean score the two years for each teacher was correlated with adversity quotient dimension of ownership mean score.

To determine the adversity quotient score of teachers, the researcher summed up the scores then multiplied by 2.The total score for individuals AQ according to Stoltz (1997) is 200. The performance rating of teachers as obtained from them was held with utmost confidentiality. Descriptive statistics were used to describe the professional qualification and length of service. T-test was used to test the difference when were classified according to professional qualification and length of service. Pearson Product Moment correlation coefficient (r) was used to test the hypothesis while simple regression was used to determine the effect of the relationship.

\subsection{Results}

The study assessed demographic information of the respondents in terms of, length of service and professional qualifications and findings are presented in the Table 1: 
Table 1: Demographic information of the Teachers

\begin{tabular}{llllll}
\hline Variable & F & $\%$ & Mean & Std. Deviation & Description \\
\hline $\begin{array}{l}\text { Professional } \\
\text { Qualification }\end{array}$ & & & & & \\
$\begin{array}{l}\text { M.Ed. } \\
\text { B.Ed }\end{array}$ & 27 & 6.2 & 48.0 & 4.0 & Above av. \\
Dip.ED & 400 & 90.70 & 45.0 & 8.2 & Average \\
& 14 & 3.17 & 44.0 & 3.0 & Average \\
\hline Length & of & & & & \\
Service & & & & & Low \\
0-5 & 36 & 7.9 & 30.0 & 5.5 & Low \\
6-11 & 116 & 26.3 & 20.9 & 7.9 & Low \\
$12-15$ & 130 & 29.5 & 30.1 & 8.6 & Low \\
$16-20$ & 104 & 23.6 & 301 & 7.9 & Low \\
$21-59$ & 55 & 12.5 & 30.0 & 7.8 & \\
\hline
\end{tabular}

Table 1 indicates that $70(6.12 \%)$ teachers had master's degree with a mean of 48.0 and standard deviation of 4 in ownership of adversity quotient meaning that they were above average and hence able to take action in adverse situations. It was revealed that $40(90.7 \%)$ were holders of bachelors degree and mean 45.0 and standard deviation of 8.2 which is an average score and fall under category of campers. Others $14(3.17 \%)$ of teachers were diploma holders with a mean of 44.0 and standard deviation of 3.0 also categorized under campers.

Regarding the length of service, $36(7.9 \%)$ teachers had served for 5 years and below. Another proportions $116(26.3 \%)$ had served between 6-11 years. One hundred and thirty (29.5\%) had served between $12-15$. One hundred and four (23.6\%) had served between 16-20 years and 55(12.5\%) teachers had served for 21 years and above. All the teachers were qualified to teach in secondary school as per teachers services regulations (TSC, 2016).All the teachers grouped under length of served had low score in ownership dimension of AQ.

We tested the relationship between adversity quotient and professional qualification of teachers through ttest. The results were positive, $\mathrm{t}=82.248$ at significant level $5 \%$ which is greater that than the critical $t$. The null hypothesis was therefore rejected. There is a significant difference in teacher's ownership dimension when grouped according to Professional qualification $\mathrm{t}$-value is greater than the $\mathrm{P}$ value $\mathrm{t}=82.248, \mathrm{P}=0.05$ as presented in Table 2.

Table 2: t-test for Ownership Dimension and Professional Qualification One-Sample Test

\begin{tabular}{|c|c|c|c|c|c|c|}
\hline & \multicolumn{6}{|c|}{ Test Value $=0$} \\
\hline & \multirow[b]{2}{*}{$\mathrm{T}$} & \multirow[b]{2}{*}{ df } & \multirow{2}{*}{$\begin{array}{l}\text { Sig. }(2- \\
\text { tailed) }\end{array}$} & \multirow{2}{*}{$\begin{array}{c}\text { Mean } \\
\text { Difference } \\
\end{array}$} & \multicolumn{2}{|c|}{$\begin{array}{l}95 \% \text { Confidence Interval of the } \\
\text { Difference }\end{array}$} \\
\hline & & & & & Lower & Upper \\
\hline educational & 82.248 & 431 & .000 & 1.08102 & 1.0552 & 1.1069 \\
\hline ownership dimension & 79.404 & 436 & .000 & 3.06865 & 2.9927 & 3.1446 \\
\hline
\end{tabular}

The study also used t-test to establish the relationship between teachers' AQ dimension of ownership and the experience. The findings are presented in Table 3.

Table 3: t- test on AQ ownership dimension and length of service

\begin{tabular}{|c|c|c|c|c|c|c|}
\hline \multirow{4}{*}{$\begin{array}{l}\text { ownership dimension } \\
\text { Years in service as a }\end{array}$} & \multirow[b]{2}{*}{$\mathrm{t}$} & \multirow[b]{2}{*}{ Df } & \multirow[b]{2}{*}{ Sig. (2-tailed) } & \multirow{2}{*}{$\begin{array}{c}\text { Mean } \\
\text { Difference }\end{array}$} & \multicolumn{2}{|c|}{$\begin{array}{l}95 \% \text { Confidence Interval of } \\
\text { the Difference }\end{array}$} \\
\hline & & & & & Lower & Upper \\
\hline & 79.404 & 436 & .000 & 3.06865 & 2.9927 & 3.1446 \\
\hline & 56.096 & 438 & .000 & 3.10934 & 3.0004 & 3.2183 \\
\hline
\end{tabular}

Table 3 indicates that there was a significant difference in teachers' ownership of adversity quotient when grouped according to the length of service $\mathrm{t}=79.404, \mathrm{P}<0.05$. The probability level of ratio is less than 0.05 . Thus, the null hypothesis was rejected. This means that length service is a determinant of ownership dimension of adversity quotient.

The third objective was to establish relationship between teachers' adversity quotient ownership dimension and students' academic. The Kenya certificate of secondary examination results 2015 and 2016 was used as the standardized score and were summarized into mean scores, and standard deviation as indicated in Table 4. 
Table 4: Students Performance 2015 and 2016

\begin{tabular}{llclll}
\hline Year & $f$ & $\%$ & Mean & Standard deviation & Description \\
\hline 2015 & 441 & 100 & 3.552 & 1.590 & D grade: below average \\
2016 & 441 & 100 & 2.738 & 1.202 & D- grade: below average \\
Average score & 441 & 100 & 3.145 & 1.396 & D grade: below average \\
\hline
\end{tabular}

The KCSE results 2015 and 2016 shows an average mean of 3.145 and standard deviation of 1.396 . The mean average grade was D plain which is below average.

A Pearson correlation moment was carried out to establish the relationship between teachers' ownership dimension of adversity quotient and students' academic. This was to test the null hypothesis that; there is no significant relationship between teachers' adversity quotient ownership dimension and students' academic performance. The results are shown in Table 5.

Table 5: Pearson correlation moment on ownership dimension and students' performance

\begin{tabular}{llrr}
\hline & & Ownership Dimension & Students Performance \\
\hline Ownership Dimension & Pearson Correlation & 1 & $.392^{* *}$ \\
& Sig. (2-tailed) & & .000 \\
& N & 441 & 441 \\
Students Performance & Pearson Correlation & $.392^{* *}$ & 1 \\
& Sig. (2-tailed) & .000 & 441 \\
& N & 441 & \\
\hline
\end{tabular}

**. Correlation is significant at the 0.01 level (2-tailed).

The results indicate that there was a positive and strong relationship between teachers' AQ dimension of ownership and their students' academic performance $(\mathrm{r}=.392, \mathrm{P}<0.01)$. The null hypothesis was rejected.

A Simple Linear regression test was run to determine the predictive power of teachers' adversity quotient ownership dimension on students' academic performance as shown on table 6 .

Table 6: Model Summary

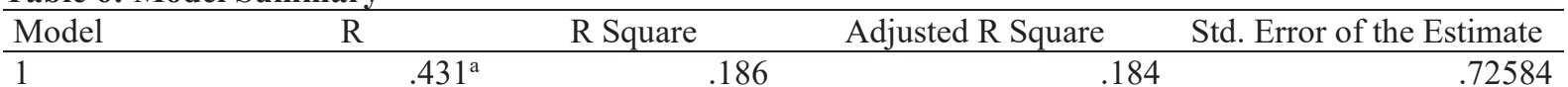

a. Predictors: (Constant), students performance

Adjusted R squared is coefficient of determination which states the variation in the dependent variable due to changes in the independent variable. The value of adjusted $\mathrm{R}$ squared was 0.184 an indication that there was variation of $18.4 \%$ due to the effect of teachers' ownership of adversities in school to changes at $99 \%$ confidence interval. $\mathrm{R}$ is the correlation coefficient which shows the relationship between the study variables, There was a positive relationship between teachers ownership of adversties in school and students academic performance by 0.43. This means by holding teachers responsible for their students' academic performance schools can improve their students' academic performance.

The model is significance through application of Analysis of Variance (ANOVA) method. The outcomes are illustrated below in table 7 .

Table 7: Analysis if variance

ANOVA ${ }^{a}$

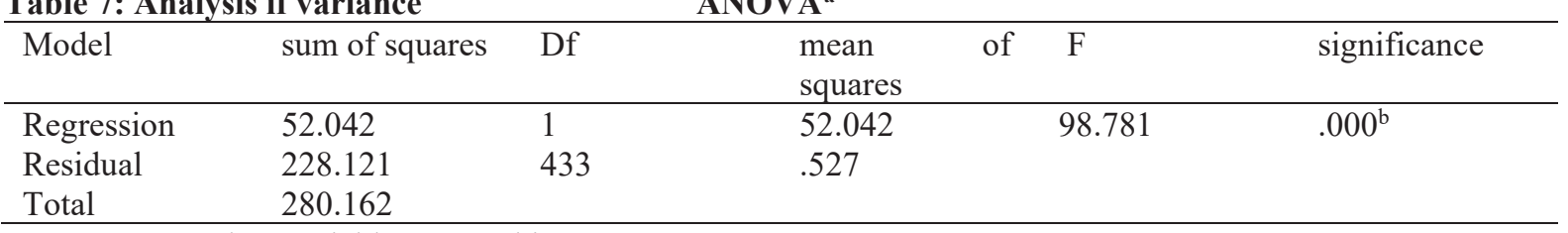

a. Dependent variable: ownership

b. Predictor:(constant) students performance

The F critical at 0.01 level of significance, 1d.f, 433 while F calculated was 98.781 . Since f calculated is greater than $\mathrm{F}$ critical this shows that the overall model was significant and therefore the null hypothesis was rejected. This shows that there is a significant relationship between teachers' adversity quotient ownership dimension and their students' academic performance. Teachers' accountability and responsibility over challenges in school affecting students' academic performance is important in improving students' academic performance. 
Table 8: Coefficients

The researcher further sought to establish the extent of impact of teachers' ownership dimension on students' academic performance through simple regression analysis.

Formula: $\mathrm{Y}=$ constant $+\mathrm{B}_{1} \mathrm{X}_{1}$

Where $\mathrm{Y}=$ performance,

$\mathrm{X}_{1}=$ Ownership

Table 8: Regression analysis coefficients

\begin{tabular}{|c|c|c|c|c|c|c|}
\hline & & Unstandardize & Coefficients & $\begin{array}{l}\text { Standardized } \\
\text { Coefficients }\end{array}$ & & \\
\hline Model & & B & Std. Error & Beta & $\mathrm{T}$ & Sig. \\
\hline 1 & (Constant) & 2.222 & .092 & & 24.220 & .000 \\
\hline & students performance & .269 & .027 & .431 & 9.939 & .000 \\
\hline
\end{tabular}

It was observed that holding teachers to account for adversities in school would increase students' academic performance by 2.222 . Two units of teachers' ownership of school adversity in school would increase students' performance by 0.296 units at $1 \%$ level of significance and 99 level of confidence.

\section{Discussions}

The study sought to establish the relationship between the teachers' adversity quotient dimension of ownership when they are classified according to professional qualification. Data on the academic rank indicate that teachers with masters' degrees had higher AQ compared to those with bachelors' degree and diploma. The results of the ttest revealed that there is a relationship between teachers AQ ownership dimension when grouped according to professional qualification $\mathrm{t}=82.248, \mathrm{P}=0.05$. This means that professional qualification is predictor of students' performance. This could be because teachers have become well versed with strategies and ways of coping with various complexities in teaching and learning process. These teachers have attained theses qualifications through hard work and perseverance. In other words, most teachers were able to overcome challenges that occurred in their lives as well as the problems experienced by students in school. They have become resistance to stressful situations, tension and depression. The results agree with those of Bautista, (2015) argue that professors have higher adversity quotient produce better results compare with those without the required capabilities. However, the findings differ with Shen (2014) who found no significant difference in adversity quotient when respondents were grouped according to education qualifications.

Regarding teachers' ownership dimension of AQ when grouped according to length of service. The results indicate that there was a positive significant relationship $\mathrm{t}=79.404, \mathrm{P}<0.05$. The results imply that teachers who have served for longer periods are likely to take action over school challenges compared to those with less experienced in teaching. Therefore, teachers' length of service is a predictor of teachers' AQ and students' academic performance. These results confirm those of Bautista (2015) $\mathrm{t}=0.0014, \mathrm{P}=0.05$ and Shen (2014) who found a significant difference between adversity quotient and length of service $t=123,128,139, \mathrm{P}=0.000$. However results of Thi (2015) while comparing AQ and the big five in predicting job performance did not find significant relationship between the overall score of AQ but found that the dimension of ownership revealed a subjective ratings of performance $(\mathrm{r}=.51$ but no objective job performance suggesting that perceiving responsibility over an event is important in predicting performance.

The study also established a significant relationship between teachers Adversity Quotient dimension of ownership and students' academic performance $(r=.392, \mathrm{P}<0.01)$. It was observed that holding teachers to account for adversities in school would increase students' academic performance by 2.222 . Therefore, 2 units of adversity quotient leads to an increase in students' performance by 0.296 units at $1 \%$ level of significance and 99 level of confidence. This implies that teachers' Adversity Quotient dimension of ownership influenced students' academic performance in a positive way. Teachers who scored high in the dimension of ownership had their students performing highly in their subjects and those with low score of ownership had their students performing poorly. These results were a true reflection of the students' academic performance in Kiambu and Nairobi counties. The results confirm the findings of Bautista (2015; Bakare, 2015; Yazon and Manaig (2018) that Adversity quotient ownership dimension is positively correlated to students' academic performance. This signifies that teachers with high ownership ability are likely to perform well in their subjects. Such teachers are likely to tap to their extra ordinary abilities and reach full potential.

\section{Conclusion}

The role of adversity quotient provides a positive contribution for education institutions to maximize the use of their human resource. There is need to take challenges objectively and positively as an opportunity that is not harmful to colleagues or the institution. Given the high degree of transparency and performance expectation from secondary school teachers by stake holders, the ability to respond to adversity effectively is vital. Adversity quotient is a factor of success in obtaining positive performance outcomes and in dealing with day to day operations 
in schools. Therefore, the study found a significant relationship between teachers' adversity quotient dimension of ownership when classified according to professional qualification, length of service and students' academic performance. The results of this study can be useful for educational managers and teachers in school management in an effort to improve students' performance outcomes. It is expected that further research can add other variables, larger and more diverse to respondents. The study can be replicated to capture students, parents and other education stakeholders in dealing with life adversities.

\section{References}

Andriani Kusumawati ( 2017) . Study on destination image, satisfaction, trust and behavioral intention. RJOAS, 1(61), January 2017

Bakare, B. M. (2015). Students' adversity quotient and related factors as predictors of academic achievement in the west african senior school certificate examination in southwestern Nigeria. Ibadan (Nigeria): University of Ibadan.

Bautista M.J.C., (2015). Adversity Quotient and teaching Performance of Faculty Members. International Journal of Scientific and Research Publication, volume 5, Issue3, March 2015

Dorji, R., \& Singh, K. (2019). Role of Adversity Quotient in Learning. International Journal of Education. Saeid, N., \& Eslaminejad, T. (2017). Relationship between Student's Self- Directed-Learning Readiness and Academic Self-Efficacy and Achievement Motivation in Students. Journal

Ferrer, M (2009). Relationship of Personal Characteristics, Leadership Styles, and Job Satisfaction to Adversity Quotient of Academic Heads of Selected Colleges and Universities in the National Capital Region. Unpublished Dissertation of the Polytechnic University of the Philippines. Retrieved from www. peaklearning.com (accessed June 5, 2012).

Fick, F. E. (2017). Well-being in Healthcare: Psychological Well-Being, Burnout, and Work Engagement in LongTerm Care Employees (Doctoral dissertation, University of Saskatchewan).

Gravetter, F. J., \& Forzano, L. B. (2017). Research methods for the behavioral sciences (5th ed). Cenage Learning Asia Pte Ltd. 58

Hechanova, M. R., Waelde, L., Docena, P., et al. (2015). The development and initial evaluation of katatagan: a resilience intervention for filipino disaster survivors. Philippine Journal of Psychology 48(2), 105-131.

Hidayat, W., \& Sariningsih, R. (2018). Kemampuan Pemecahan Masalah Matematis dan Adversity Quotient Siswa SMP Melalui Pembelajaran Open Ended. JNPM (Jurnal Nasional Pendidikan Matematika), 2(1), 109-118.

Husted, H.S., (2017). The relationship between psychological well-being and successfully transitioning to university. Retrieved from http://ir.lib.uwo.ca/cgi/viewcontent.cgi?article=1062\&context=psychK uh t

Kekhet K. (2015). The relationship between Adversity Quotient and leadership styles of Business leaders in Egypt. DBA dissertation, Maastrictht School of management, Maastricht 2015

Kenya National Examinations Council (2017). Annual Report. Nairobi. Kenya:KNEC

Khairani, A. Z., \& Abdullah, S. M. (2018). Relationship between adversity quotient and academic well-being among Malaysian undergraduates. Asian Journal of Scientific Research. DOI: 10.3923/ajsr.2018.51.55

Korna, A. (2014). To bend, but not to break. Retrieved from https://aura.antioch.edu/cgi/viewcontent.cgi?article=1176\&context=etds Ledesma, J. (2014). Conceptual frameworks and research models on resilience in leadership. July- September 2014: 1-8. Retrieved from http://journals.sagepub.com/doi/full/10.1177/2158244014545464

Lo, T. \& Khaled, B.E. (2015) "The Relationship of Adversity Quotient and Leadership Styles of Private Business Leaders in Egypt" Retrieved in December 2015, from: http://gssrr.org/index.php?journal=JournalOfBasicAndApplied

Matore, M.E.E.M., Khairani, A.Z., \& Razak, N.A. (2015). The influence of AQ on the academic achievement among Malaysian Polytechnic students. International Education Studies, 8(6), 69-74.

Micheal Vincent B. Ablana \& Daniel J. Isidro (2016). Correlation between adversity quotient and job performance of LGU Employees at Tayabas City: input to effective public personnel management.Retrived : peaklearning/ wp.content/ upload/ 2019/05/PEAK/GRI/Isidro Ablana/pdf

Ministry of education science and technology 2015) National education sector plan volume one: Basic education programme rational and approach.

Ministry of education science and technology, KNEC 2016: KCSE Examination county order merit order ministry of education eduction science and technology Nairobi, Kenya, 2016.

Monica Joy O. Daloos November (2015) . Emotional intelligence and adversity quotient of selected helping professionals. A master thesis Submitted to the Department of Psychology Institute of Arts and Sciences Far Eastern University - Manila in Partial Fulfillment of the Requirements for the degree Master of Arts in Psychology

Musili, A. M. (2015). Influence of teacher related factors on students' performance in Kenya certificate of secondary education in public secondary schools in Kibwezi sub-county Kenya (Doctoral dissertation). 
Mwangi C.N. (2015). The Relationship Between Academic Resilience and Academic Achievement among Secondary School Students in Kiambu county.

Rathee, N., \& Sharma, S. (2018). Adversity Quotient among High School Students In Relation To Demographic Variables. International Journal of Humanities and Social Science Invention (IJHSSI), 7(5), 33-36.

Republic of Kenya (2013). Education Act of Kenya. Nairobi.: Government Printer

Shen C. Y. (2014). A study Investigating the Influence of Demographic Variables of Employees on Adversity Quotient. The journal of Human Resource and Adult learning,10(1), 22-32

Stoltz P. (2010). Adversity Quotient at Work: Finding your hidden capacity for getting things done. Wiley Publishers.

Lydia M. Musau and Migosi Joash Abere (2015), Teacher qualification and students' academic performance in science mathematics and technology subjects in Kenya. International Journal of Educational Administration and Policy Studies. Vol. 7(3), pp. 83-89, May, 2015 DOI:10.5897/IJEAPS2014.0386 Article Number: BAD736653197 ISSN 2141-6656 Copyright (C) 2015 Author(s) retain the copyright of this article http://www.academicjournals.org/IJEAPS

Teachers Service Commission (2016). Performance Appraisal and Development. Nairobi: TSC.

TemitopeOluwakemi Ewetan \& OlabanjiOlukayodeEwetan (2015) Teachers' Teaching Experience and Academic Performance in Mathematics and English Language in Public Secondary Schools in Ogun State, Nigeria. International Journal of Humanities Social Sciences and Education (IJHSSE)Volume 2, Issue 2, February 2015, PP 123-134ISSN 2349-0373 (Print) \& ISSN 2349-0381 (Online)www.arcjournals.org

Tian, Y., \&Fan, X. (2014). Adversity quotients, environmental variables and career adaptability in student nurses. J. Vocat. Behav.,85(3), 251-257.

Tigchelaar, A., \&Khaled, E. B. (2015). The Relationship of Adversity Quotient and Leadership Styles of Private Business Leaders in Egypt. International Journal of Sciences: Basic and Applied Research (IJSBAR), 20(2),20-48.

Usha, P., \& Praseeda, M. (2014). Relationship between Adversity Quotient and Academic Problems among Student Teachers. Journal of Humanities and Social Science (IOSR-JHSS), 19(11),23-26.

Venkatesh J. et al., (2015). Adversity Quotient Profile: An effective psychometric tool to Hire the Finest Aspirant for Contemporary Organization. Scholar Journal of Economies, 2 (12) 1159-1164

Verma, S., Aggarwal, A., \& Bansal, H. (2017). The relationship between emotional intelligence (EQ) and adversity quotient (AQ). IOSR Journal of Business and Management (IOSR- JBM), 19(1), 49-53. IORS journal of Business and management. Volume 19, issue 1, 2017

Wango G. M. (2011). Kenya new constitution and education. Education in Kenya under the new constitution: Nairobi. paper presented to the task force on the realignment of the education system to the new constitution.

Wango, G., \& Gatere, A. (2016). Integrity and Financial Accountability in Schools: Role of Principals' of Schools in Kenya. International journal of Education and Research, 4(4), 1-14.

Yazon, A. D., \& Manaig, K. A. (2018). Adversity Quotient ${ }^{\circ}$, Emotional Quotient and Academic Performance of Filipino Student-Parents. PEOPLE: International Journal of Social Sciences, 4(3).

Zubaidah Amir, M. Z. (2019). Adversity quotient in mathematics learning (Quantitative study on students boarding school in Pekanbaru) (Hasil Check Similarity).

Zubaidah, A., Risnawati, R., Kurniati, A., Prahmana, R.C.I., \& Uin, S.R. (2017). Adversity Quotient in Mathematics Learning (Quantitative Study on Students Boarding School in Pekanbaru). International Journal on Emerging Mathematics Education(IJEME), 1(2), 169-176. 